\title{
Petro physical parameter studies for characterization of gas reservoir of Narsingdi gas field, Bangladesh
}

\author{
Abu Reza Md. Towfiqul Islam ${ }^{1 *}$, Md. Aminul Islam ${ }^{2}$, Anjum Tasnuva ${ }^{1}$, Raman Kumar Biswas ${ }^{3}$, Khurshida Jahan ${ }^{4}$ \\ ${ }^{1}$ Department of Disaster Management, Begum Rokeya University, Rangpur, 5400, Bangladesh \\ ${ }^{2}$ Department of Petroleum Geoscience, Faculty of Science, Universiti of Brunei Darussalam, Gadong, 1410 \\ ${ }^{3}$ Department of Disaster Resilience and Engineering, Faculty of Disaster Management, \\ Patuakhali Science and Technology University, Patuakhali, 8602, Bangladesh \\ ${ }^{4}$ Department of Chemistry, Jahangirnagar University, Savar, Dhaka 1342, Bangladesh \\ *Corresponding author E-mail: gm_towfique_06@yahoo.com
}

\begin{abstract}
The study focused on quantitative analysis of petrophysical parameters to characterize the reservoir of Narsingdi Gas Field, Bangladesh using well log data. 12 permeable zones were identified, out of which 5 zones were gas-bearing. Shale volume of those zones were averaged at ranged from $14 \%$ to $25 \%$ indicate reservoir consists of sand dominated lithology and less influence the water saturation for the study well. Porosity of these zones were averaged as $27 \%$ which was within the ranged for very good gas accumulation. Water saturation values were less than $35 \%$ which calculated by using three equations. Gas saturation values were more than $65 \%$ revealed that high gas accumulation in these gas reservoirs. Permeability was averaged at ranged from $32 \mathrm{mD}$ to $55 \mathrm{mD}$ which was within limit for good gas accumulation. Bulk volume of water was averaged at ranged from 0.030 to 0.038 indicate fine grained sand occupied by gas reservoirs were more or less at irreducible water condition. Gas was moveable as indicated by gas moveability index $\left(\frac{S_{w}}{S_{x o}}\right)<0.7$. The study suggests that gas reservoir is potential for gas production and accumulation. The study results will contribute in future gas field development programme.
\end{abstract}

Keywords: Gas Moveability Index, Narsindhi Gas Field, Petrophysical Parameter, Reservoir Potential and Well Log Data.

\section{Introduction}

Petrophysical parameter studies are very important for the development and production of the well and estimation of the hydrocarbon reserves in any gas field. The geological model of gas reservoir is based on the estimates of reservoir properties such as lithology, porosity, permeability and fluid type [1]. Some studies were carried out regarding petrophysical analyses of shaly-sand reservoir of Bengal Basin, Bangladesh [2-5]. Rahman et al. [6] revealed to evaluate the reservoir sand of Titas-15 well, Bangladesh. Recent study was conducted by Islam et al. [7-8] to assess the gas reservoir of Rashidpur and Meghna Gas Field, Bengal basin using well log interpretation. These earlier studies were motivated by the fact that gas-bearing reservoir of Bangladesh was taken particular attention due to its highly economic interest.

In this context, the study was emphasized on the quantitative analysis of petrophysical parameters of gas reservoir in the Miocene sequence encountered in the Narsingdi Gas Field, Bangladesh using well log data. The aim of the study was to characterize the reservoir quality of Narsingdi Gas Field. It is located in the Narsingdi district adjacent to the Dhaka-Sylhet highway about
$45 \mathrm{~km}$ away of northern most from capital city of Bangladesh, Dhaka (Fig. 1).

\section{Geological framework}

Bengal Basin of Bangladesh is a young prolific depositional basin in the world [8]. This basin meets the entire geological requirement for accumulation of natural gas in the subsurface [6]. Greater Bakhrabad Structure of Bengal Basin is an elongated close anticline and is about $67 \mathrm{~km}$ long and $6 \mathrm{~km}$ wide [10]. Belabo Structure of Narsingdi Gas Field is a one of the part of greater

Bakhrabad structure which randomly egg like shaped anticline whose run slightly longer N-S axis [11]. It is located in the crestal region of Bakhrabad anticline. Belabo structure is the smaller part of other Bakhrabad and Morichakandi structures forming the greater Bakhrabad anticlinal complex. The greater Bakhrabad Structure lies on the southern fringes of the Sylhet Trough of Bengal Basin. 


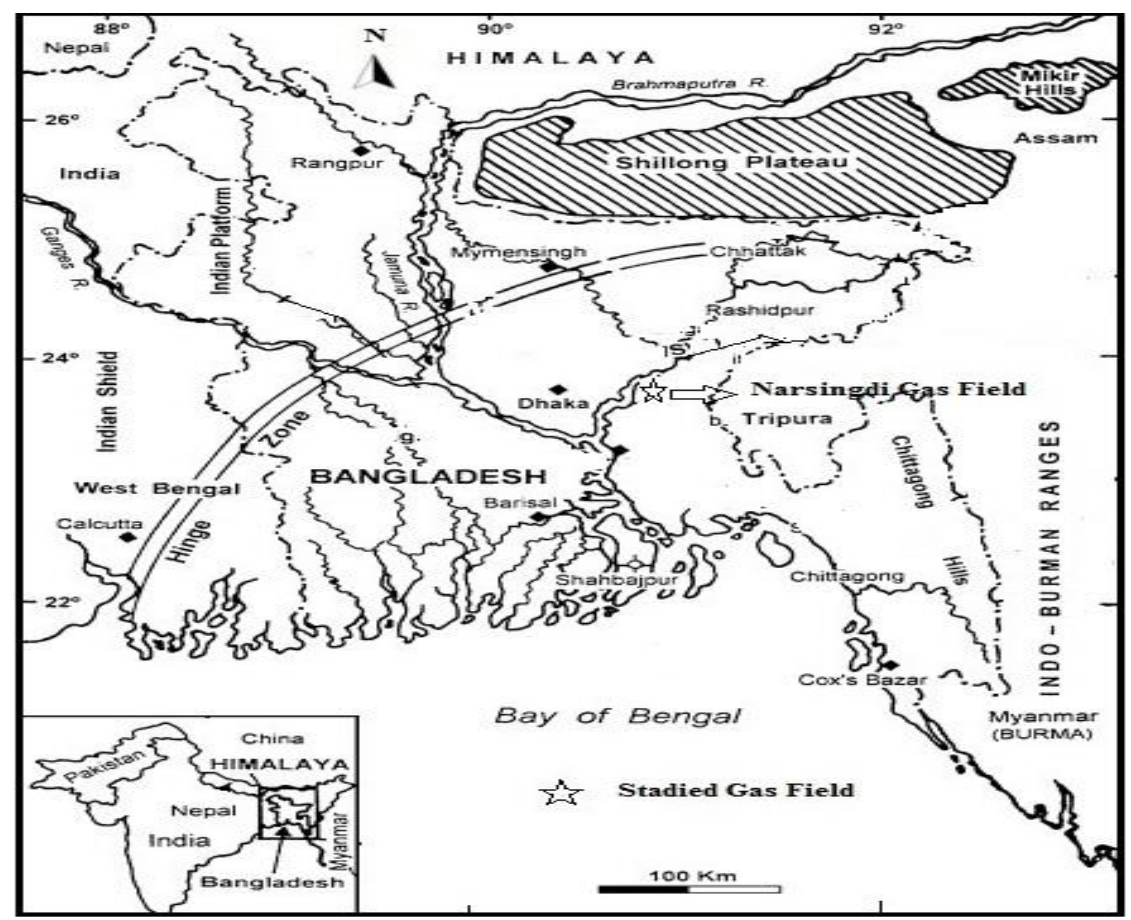

Fig. 1: Location Map Showing the Narsingdi Gas Field (After Modified Alam Et Al. [9])

\section{Materials and methods}

Well log data was collected from the data Centre, Petro Bangla. So, hand copy of well logs including gamma ray (GR), selfpotential (SP), resistivity logs (MSFL and ILD), density log (RHOB) and neutron log (NPHI) etc. were digitized manually keeping restraint to regenerate for the study well Bakhrabad-10. Primary study is related to data quality, depth correction, sand and shale zone identification were carried out on paper based logs. The study gas field was covered with the depth ranges of 867-3440 m. Permeable zones were identified with the help of GR, SP, resistivity, neutron and density composite log responses. Well log data were analyzed using MS-Excel software. Detailed petro physical parameters were estimated by the following equation for the study.

\subsection{Shale volume}

Before the calculating the shale volume, the gamma ray index was the first step to estimate with the help of gamma ray log (GR) using Schlumberger [14] formula.

$I_{G R}=\frac{G R_{\log }-G R_{\min }}{G R_{\text {mix }}-G R_{\min }}$

Where, $I_{G R}=$ Gamma ray index, $G R_{\log }=$ Gamma ray reading of formation, $G R_{\min }=$ Minimum gamma ray (for clean sand), $G R_{\max }=$ Maximum gamma ray (for shale).

Shale volume $\left(V_{S h}\right)$ was calculated from the gamma ray index $\left(I_{G R}\right)$ for tertiary unconsolidated rocks Dresser Atlas [13]. So, the study reservoirs are made of unconsolidated sandstone rock. The following equation was used to calculate shale volume and written as:

$V_{s h}=0.083\left[2^{3.7 \times I_{G R}}-1.0\right]$

\subsection{Porosity}

After calculation of the shale volume $\left(V_{s h}\right)$ is to correct the shale effect for calculation of porosity. The following equation proposed by Dresser Atlas [13] was used to estimate porosity using available neutron and density logs:

$\emptyset_{\text {Den }}=\left(\frac{\rho_{m a}-\rho_{b}}{\rho_{m a}-\rho_{f}}\right)-V_{s h}\left(\frac{\rho_{m a}-\rho_{s h}}{\rho_{m a}-\rho_{f}}\right)$

$$
\begin{aligned}
& \emptyset_{N c o r r}=\emptyset_{N}-\left[\left(\frac{\emptyset_{N c l}}{0.45}\right) \times 0.30 \times V_{s h}\right] \\
& \emptyset_{\text {Dcorr }}=\emptyset_{D}-\left[\left(\frac{\emptyset_{N c l}}{0.45}\right) \times 0.13 \times V_{s h}\right]
\end{aligned}
$$

Both neutron-density logs were also used to calculated porosity (Ø) [14].

$\emptyset_{N^{-} D}=\sqrt{\frac{\emptyset_{N c o r r}{ }^{2}+\emptyset_{D c o r r^{2}}}{2.0}}$

Where, $\emptyset_{D}=$ density derived porosity, $\emptyset_{N}=$ neutron derived porosity, $\rho_{D}=$ matrix density (sandstone), $\rho_{b}=$ bulk density (log reading), $\rho_{f}=$ fluid density (for water $=1.0 \mathrm{~g} / \mathrm{m}$ and for gas $=0.7 \mathrm{~g} / \mathrm{m}$ ), $\rho_{\text {sh }}=$ shale density.

\subsection{Water saturation}

Next step for calculation of water saturation $\left(S_{w}\right)$ by the following three equations were used for shaly-sand gas reservoir for this research:

$$
\begin{aligned}
& S_{w}=\left(\frac{0.4 \times R_{w}}{\emptyset^{2}}\right)\left[\frac{V_{s h}}{R_{s h}} \sqrt{\left(\frac{V_{s h}}{R_{s h}}\right)^{2}+\frac{5 \emptyset^{2}}{R_{t} \times R_{w}}}\right] \\
& S_{w}=\frac{1}{\emptyset} \times\left[\sqrt{\frac{R_{w}}{R_{t}}+\left(\frac{a \times V_{s h}}{2}\right)^{2}-\frac{a \times V_{s h}}{2}}\right] \\
& S_{w}=\frac{\frac{V_{s h}}{R_{S h}} \sqrt{\left(\frac{V_{s h}}{R_{s h}}\right)^{2}+\frac{\phi^{2}}{0.2 \times R_{w} \times\left(1.0-V_{s h}\right) \times R_{t}}}}{\frac{\phi^{2}}{0.4 \times R_{W} \times\left(1.0-V_{s h}\right) \times R_{t}}}
\end{aligned}
$$

Where, $R_{s h}=$ Shale resistivity, $R_{w}=$ formation water resistivity, $R_{t}=$ true resistivity from the deep resistivity $\log , \mathrm{a}=1$ (tortusity factor).

Simandoux [15], Fertl [16] and Schlumberger [17] equation 7, 8 \& 9 were used to estimate water saturation. Equation was used for calculating the formation water resistivity of gas-bearing zone Bateman and Konen[18].

$$
R_{w}=10\left\{\frac{S S P}{K}+\log R_{w}\right\}
$$

\subsection{Gas saturation}

Gas saturation is depend on water saturation and is the part of pore volume in a formation occupied by gas. It was calculated by the following equation.

$S_{h}=100-S_{w}$ 


\subsection{Permeability}

Permeability has been estimated from the following equation by Coates and Dumanoir [19].

$\mathrm{K}=\left(\frac{c \times \emptyset^{2 w}}{W^{4} \times\left({ }^{R_{w}} / R_{\text {tirr }}\right)}\right)^{2}$

Where, $\mathrm{W}=\left[(3.75-\varphi)+\left\{\frac{\left[\log \left(\frac{R_{W}}{R_{\text {tirr }}}\right)+2.2\right]^{2}}{2}\right\}\right]^{1 / 2}$

$$
\mathrm{c}=23+46 \rho_{h}-188 \rho_{h}^{2}
$$

Permeability was calculated by using the Wyllie and Rose [20] equation which is given:

$\mathrm{K}=\left(79 \times \emptyset^{3} / S_{\text {wirr }}\right)^{2}$

Where, $S_{\text {wirr }}=$ saturation at irreducible water saturation, $R_{\text {tirr }}=$ deep resistivity at irreducible water resistivity, $\mathrm{SSP}=$ Static Self Potential, w and $\mathrm{c}=$ constant on hydrocarbon density, $\rho_{h}=$ gas density (0.7 for gas)

\subsection{Gas moveability index}

Gas moveability index is expressed of the following equation by Archie [21]:

$\frac{S_{w}}{S_{x o}}=\left[\frac{R_{x o} \times R_{w}}{R_{t} \times R_{m f}}\right]^{1 / 2}$

Where, $S_{x o}=$ flushed zone water saturation, $R_{m f}=$ mud filtrate resistivity, $R_{x o}=$ formation shallow resistivity.

\subsection{Bulk water volume}

The bulk water volume (BVW) was calculated using Morris and Biggs [22] equation for the study.

$\mathrm{BVW}=S_{w} \times \emptyset$

Where, $S_{w}=$ Water saturation of uninvaded zones and $\emptyset=$ porosity

\section{Results}

Petrophysical parameters such as lithology, shale volume, porosity, saturation, bulk water volume and permeability were used to evaluate the gas-bearing reservoir characteristics. In the study gas field, 12 permeable zones were identified from the analyses of composite log response (Table 1). Among these permeable zones, five zones were identified as gas-bearing while remaining is water-bearing.

\subsection{Gas-bearing zones identification}

Gas-bearing zones of the shaly-sand sequence were identified with the help of composite log responses (Fig. 2, 3, 4 and 5)

Table 1: Presentation of Permeable Zones of the Miocene Sequence in Narsingdi Gas Field, Bangladesh.

\begin{tabular}{ccc}
\hline Zone No. & Zone Type & Depth Range $(\mathrm{m})$ \\
\hline 1 & Water-bearing & $1850-1872$ \\
2 & Water-bearing & $1955-1950$ \\
3 & Water-bearing & $1972-1990$ \\
4 & Water-bearing & $2005-2018$ \\
5 & Water-bearing & $2145-2155$ \\
6 & Water-bearing & $2182-2198$ \\
7 & Water-bearing & $2225-2242$ \\
8 & Hydrocarbon-bearing & $2915-2617$ \\
9 & Hydrocarbon-bearing & $2993-2996$ \\
10 & Hydrocarbon-bearing & $3131-3134$ \\
11 & Hydrocarbon-bearing & $3145-3149$ \\
12 & Hydrocarbon-bearing & $3166-3169$ \\
\hline
\end{tabular}

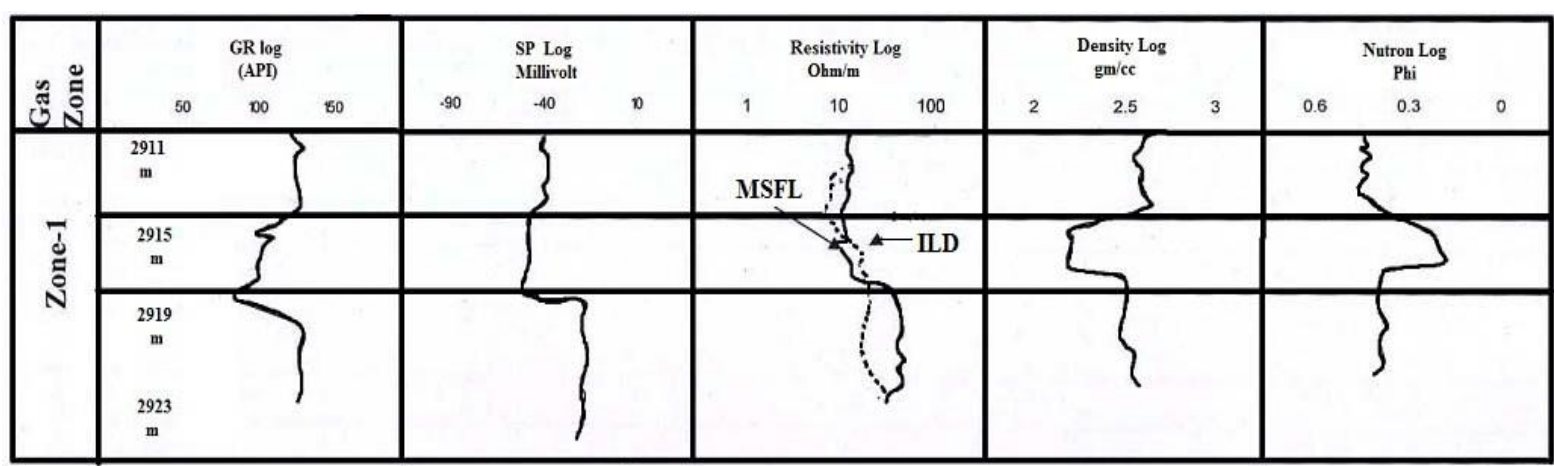

Fig. 2: GR, SP, Resistivity, Density and Neutron Log Responses of the Gas Zone-1 of the Narsingdi Gas Field

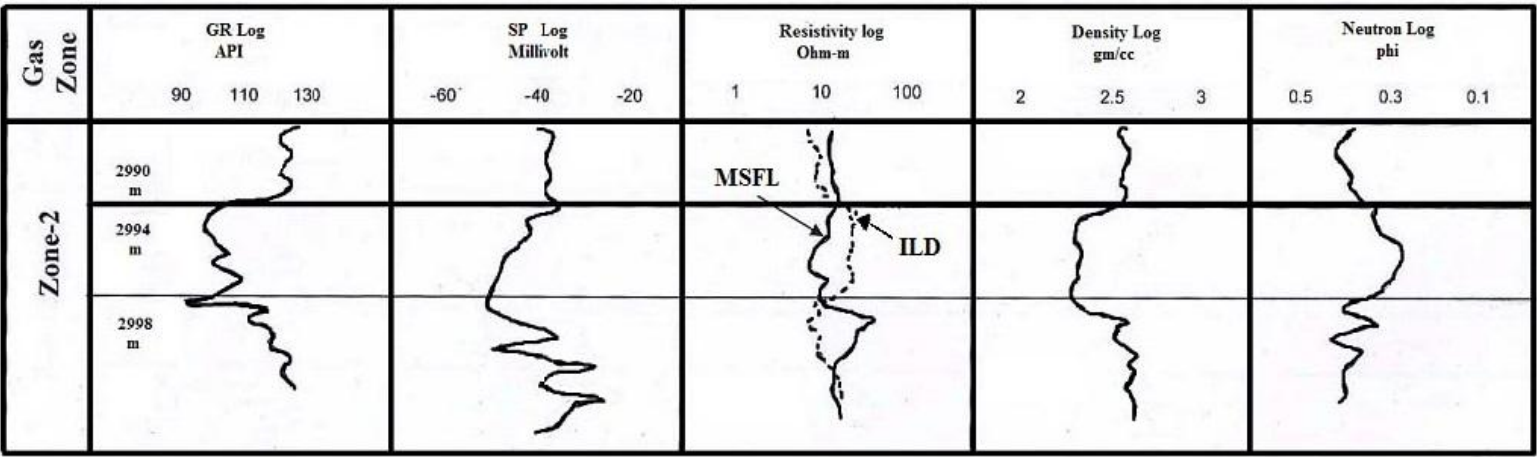

Fig. 3: GR, SP, Resistivity, Density and Neutron Log Responses of the Gas Zone-2 of the Narsingdi Gas Field. 


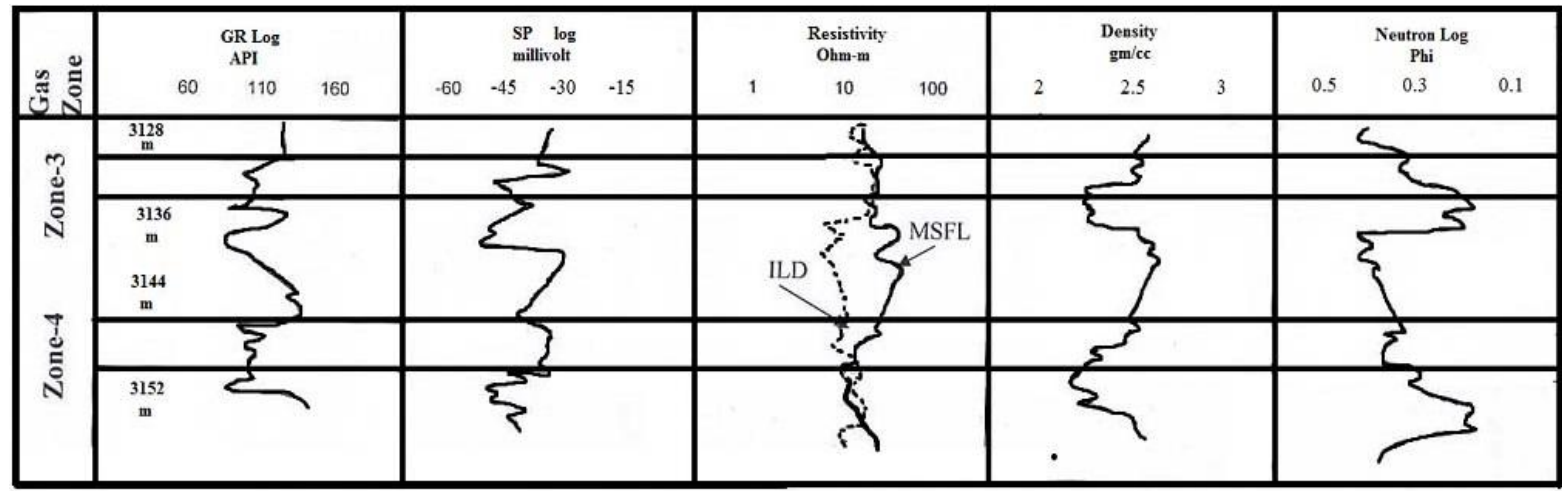

Fig. 4: GR, SP, Resistivity, Density and Neutron Log Responses of the Gas Zone-3 and Zone-4 of the Narsingdi Gas Field.

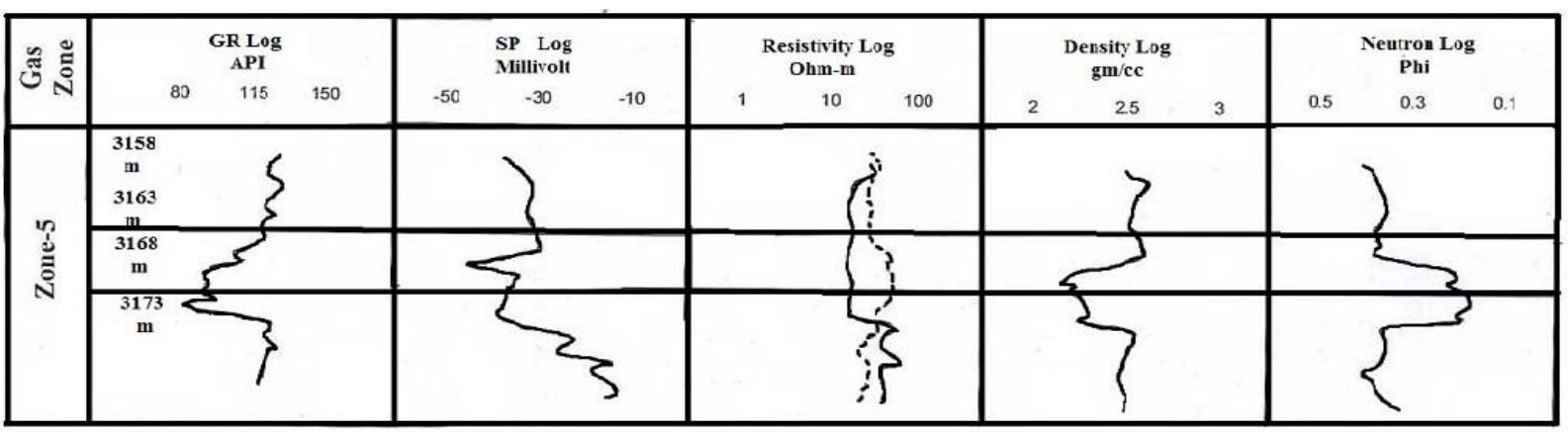

Fig. 5: GR, SP, Resistivity, Density and Neutron Log Responses of the Gas Zone-5 of the Narsingdi Gas Field.

\subsection{Shale volume}

Shale volume $\left(V_{s h}\right)$ is used to evaluate the shale distribution of a reservoir. The result of shale volumes was shown graphically in the fig. $6,7,8, \& 9$.

\subsection{Porosity and permeability}

The porosity calculation is a very important step for reservoir characterization in any gas field. Porosity and permeability distribution were shown graphically in the fig. $6,7,8$ and 9.

\subsection{Water and gas saturation}

Water saturation of gas-bearing zones has not been calculated using Archie [21] equation which is valid for clean sandstone. All of the calculated saturation value is affected by shale and porosity distribution. Three saturation equations were proposed by Simondoux [15], Fertl [16] and Schlumberger [17] to use in this present study (Fig. 6,7, 8 and 9).Water saturation values were converted to gas saturation values which was determined by subtracting water saturation from the total saturation $(100 \%)$. The permeable zone with more than $65 \%$ gas saturation values were commonly treated as gas-bearing reservoir [23].

\subsection{Gas moveability index and bulk volume of water}

If gas moveability index $\left(\frac{S_{w}}{S_{x o}}\right)$ is equal to or $>1.0$, then hydrocarbon would not move and the ratio is $<0.7$ (for sandstone) indicate gas moveable in the well bore [24]. From the calculated result, it was interpreted that gas-bearing zones are moveable because all the movability values are less than 0.7 in the study well (Table 2). $\mathrm{BVW}$ indicate the formation is at irreducible water state or not. If the BVW was at ranged from 0.035 to 0.07 , the grain size of the sand is fine to very fine-grained [25].

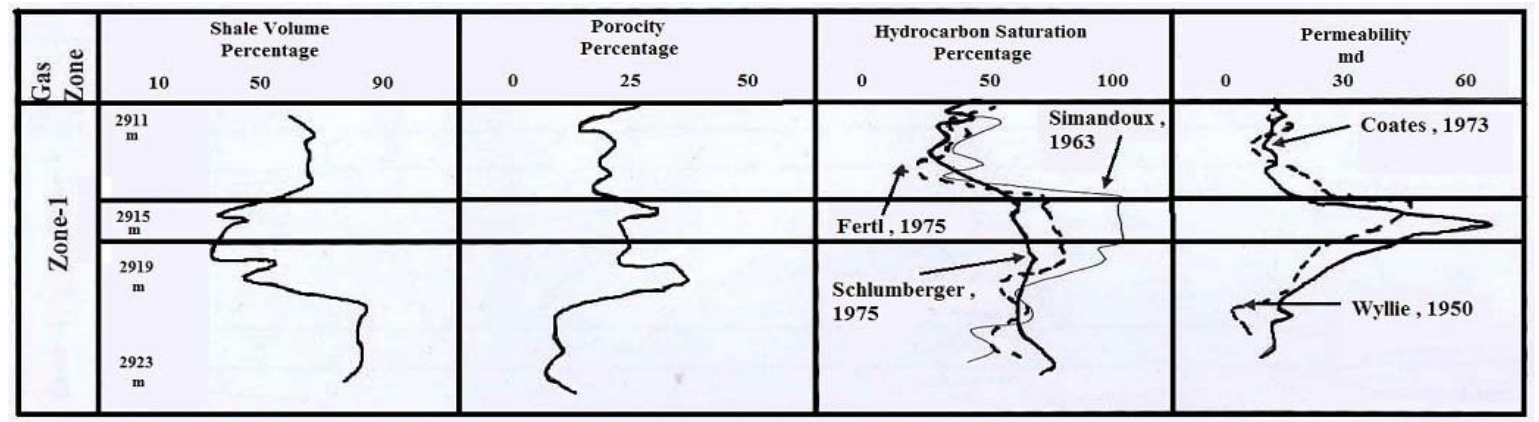

Fig. 6: Graphical Representations of Shale Volume, Porosity, Hydrocarbon Saturation and Permeability of the Gas Zone-1 of the Narsingdi Gas Field. 


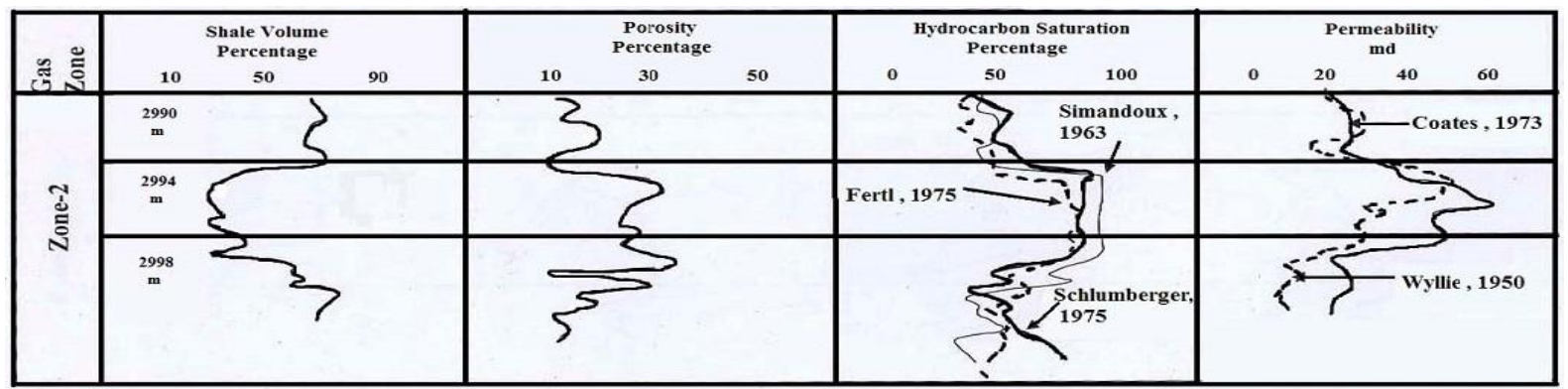

Fig. 7: Graphical Representations of Shale Volume, Porosity, Hydrocarbon Saturation and Permeability of the Gas Zone-2 of the Narsingdi Gas Field.

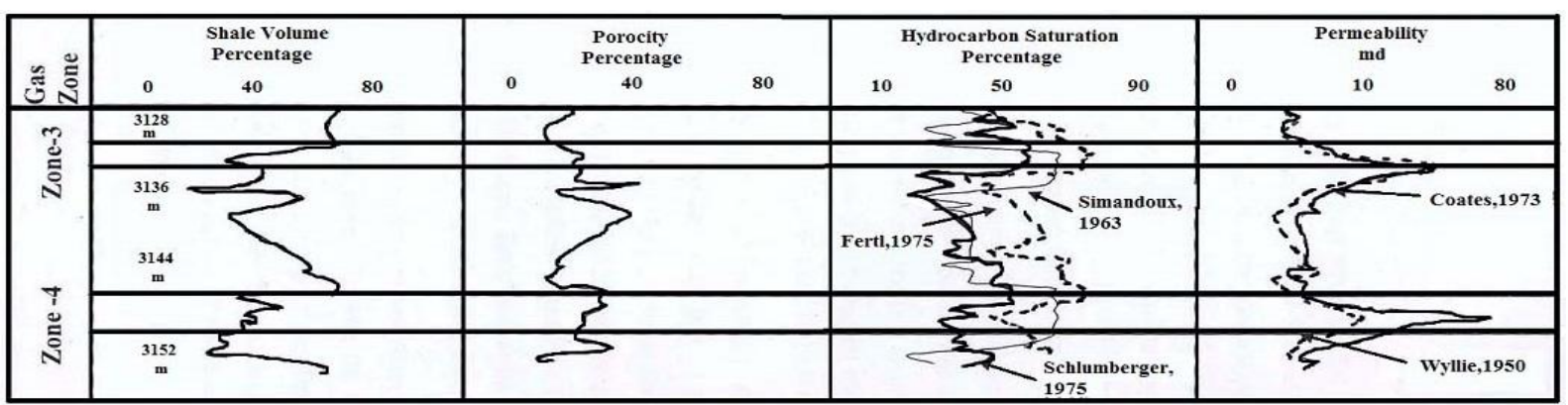

Fig. 8: Graphical Representations of Shale Volume, Porosity, Hydrocarbon Saturation and Permeability of the Gas Zone-3 \& Zone-4 of the Narsingdi Gas Field.

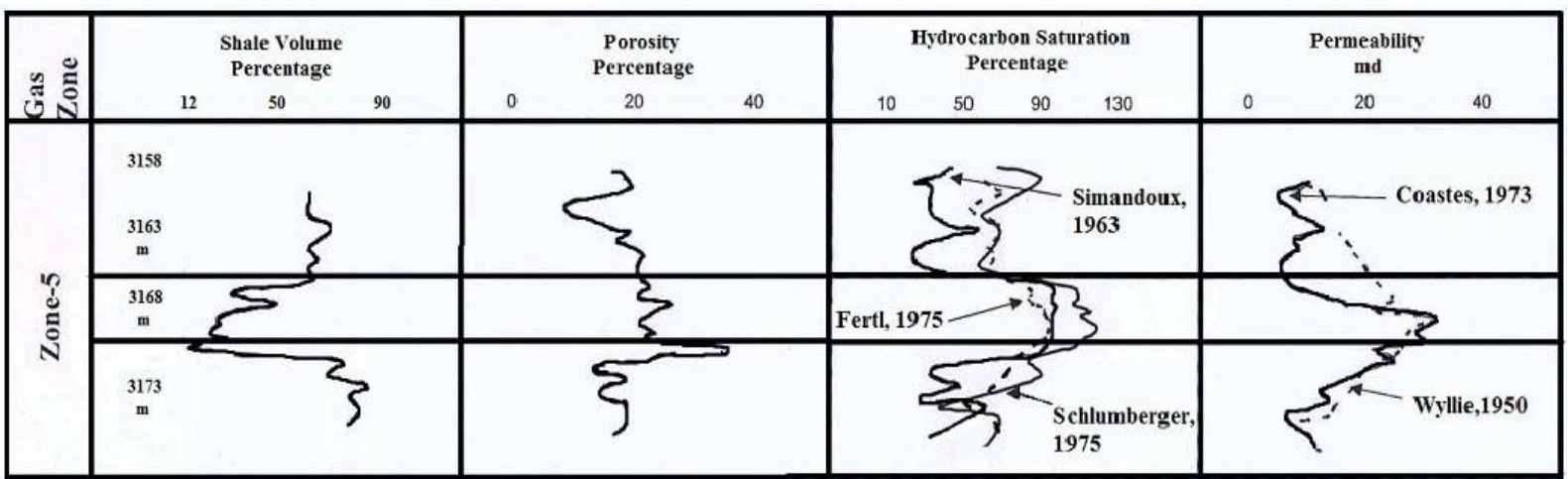

Fig. 9: Graphical Representations of Shale Volume, Porosity, Hydrocarbon Saturation and Permeability of the Gas Zone-5 of the Narsingdi Gas Field.

Table 2: Show the Values of Gas Moveability Index and Bulk Volume of Water of Gas-Bearing Zones in the Study Gas Field.

\begin{tabular}{|c|c|c|c|c|c|c|}
\hline \multirow[t]{2}{*}{ Zone No. } & \multirow[t]{2}{*}{ Depth Ranges(M) } & \multirow[t]{2}{*}{ Thickness (M) } & \multicolumn{2}{|c|}{ Gas Moveability Index $\left(\frac{S_{w}}{S_{x o}}\right)$} & \multicolumn{2}{|c|}{ Bulk Volume Of Water } \\
\hline & & & Range & Average & Range & Average \\
\hline 1 & $2915-2917$ & 2 & $0.11-0.15$ & 0.16 & $0.025-0.063$ & 0.034 \\
\hline 2 & 2993-2996 & 3 & $0.11-0.16$ & 0.15 & $0.027-0.067$ & 0.035 \\
\hline 3 & $3131-3134$ & 3 & $0.14-0.22$ & 0.16 & $0.016-0.044$ & 0.030 \\
\hline 4 & $3145-3149$ & 4 & $0.12-0.19$ & 0.13 & $0.024-0.045$ & 0.038 \\
\hline 5 & $3166-3169$ & 3 & $0.13-0.23$ & 0.13 & $0.027-0.041$ & 0.036 \\
\hline
\end{tabular}

\section{Discussions}

The study gas field potentiality was evaluated by petrophysical analysis using log data of well Bakhrabad-10. From petrophysical interpretation, five gas bearing zones were identified in the study well at depth ranges from 2915-2927 m, 2993-2996 m, 3131$3134 \mathrm{~m}, 3145-3149 \mathrm{~m}$ and $3166-3169 \mathrm{~m}$ having thicknesses of 2 $\mathrm{m}, 3 \mathrm{~m}, 3 \mathrm{~m} 4 \mathrm{~m}$ and $3 \mathrm{~m}$ respectively (Table 1). Low gamma ray (GR) responses and high SP responses indicate gas bearing reservoir zones. Higher true resistivity responses of these zones with respect to lower water resistivity responses and vice versa indicate that hydrocarbon type fluid is gas bearing. Low density responses and very low neutron responses in the gas bearing zones show that gas bearing reservoir (Fig. 2, 3, 4 and 5). Shale volume values were averaged at ranged from $14 \%$ to $25 \%$ that revised to sand volume of these gas zones were ranged from $75 \%$ to $84 \%$ revealed that reservoir is mainly sand predominant lithology in the well Bakhrabad-10 (Fig. 6, 7, 8 and 9). Similar observation of the average shale volume was made by Islam et al. [8] in the Well Bakhrabad-09. It indicates that the reservoir is evidence of sand development [26]. Porosity of those zones was averaged and their values ranged from $23 \%$ to $31 \%$ which indicate very good gas accumulation. According to porosity calculation, zone- 4 is the most prospective gas-bearing zone with respect to zone1, 2, 3, and 5 in the study well. Some recent studies were found also similar average porosity ranged in the Laja Oil Field, Rickie Field, KN Field and Y Field, Niger delta [27-30]. For assessing Narsingdi gas productivity, the calculated average permeability values of these zones were ranged from $28 \mathrm{mD}$ to $90 \mathrm{mD}$ by Coates and Domanior [19] equation while average permeability values ranged From $28 \mathrm{mD}$ to $40 \mathrm{mD}$ was followed by Wyllie and Rose [20] equation. According to Coates permeability equation was found better result of reservoir characterization except zone-3 and zone-5 than Wyllie equation. So, the ratio of average porosity and permeability values were $27 \% / 46 \mathrm{mD}(58.69 \%)$ indicate good enough to permit free fluid flow of these gas bearing zones. There were 
positive correlation between porosity and permeability in the study well Bakhrabad-10 (Figure 6, 7, 8 and 9). The average gas saturation values of these zones were estimated by three equations at $68 \%$ by Simondoux [15] followed by $88 \%$ Fertl, [16] and $90 \%$ using by Schlumberger [17] equation. All the calculated more than $65 \%$ values of the gas saturation suggested that reservoir was assembled very high gas accumulation. These results are very close to previous finding elsewhere gas field in the Bengal Basin [3-5]. Gas moveability index values were averaged at range from 0.13 to 0.16 which was less than 0.7 in the study well Bakhrabad-10 that suggest gas in the well will move freely. BVW values were averaged at range from 0.030 to 0.038 indicates sand in reservoir is fine grained (Table 2). Calculated values of BVW are constant or very close to constant, it indicate that the zones is homogenous at irreducible water condition [31]. Both gas moveability index and BVW were found acceptable for gas production. Titas Gas Field and Shahbazpur Gas Gield were found similar finding by Islam et al [2-3].

\section{Conclusion}

The Quantitative analysis of petrophysical parameters were used to characterize the gas reservoir quality of the Narsingdi Gas Field by using well logs such as GR logs, SP logs, resistivity logs, neutron logs and density logs. 5 gas-bearing zones were identified in the study well Bakhrabad-10 on the basis of low GR, high SP, high resistivity, low neutron and low density log responses. The gas reservoirs were shown an average shale volume of about $19.5 \%$ and average porosity of 27 . All the calculated values of gas saturation were more than $65 \%$ treated as gas-bearing zones. The average permeability of these gas zones were estimated at $32 \mathrm{mD}$ to 55 $\mathrm{mD}$ by using two permeability equations. It revealed that there were positive correlations between porosity and permeability of gas-bearing zones in the study well. The composite log response and all the calculated petrophysical parameters of gas-bearing zones suggest gas reservoir is potential for commercial gas production and accumulation. The study recommended that 3-D seismic study integrated with well log study will depict more detailed picture of the gas reservoir in the study gas field.

\section{Acknowledgments}

Thanks are due to the Chairman of Bangladesh Oil, Gas and Mineral Corporation (Petrobangla) and the Managing Director, BAPEX for their kind permission and access to well log data while conducting this research work. This research was performed by self-funded.

\section{References}

[1] Bhatt a \& Helle HB (2002), Determination of facies from well logs using modular neural networks. Petroleum Geoscience 8, 217-228

[2] Islam MA, Islam MS, Latif MH, Mondal D \& Mahbub MA (2006), Petrophysical analysis of shaly-sand gas reservoir of Titas Gas Field using well logs. Bangladesh, Journal of Geology 25, 106-124.

[3] Islam MA, Islam, MS \& Mondal D (2007), Log derived shaly-sand analysis of Shahbazpur Gas Field, Bhola, Bangladesh. Bangladesh Geoscience Journal 13, 63-77.

[4] Islam MA, Islam MS, Talukder S, Haque KE, Rahman MA \& Ahmed F (2009), Petrophysical evaluation of Neogene Shaly-sand gas reservoir: A case study of Kailas Tila Gas Field; Bengal Basin, Bangladesh. International Journal of Earth Science and Engineering 2, 499511.

[5] Islam MA (2010), Petrophysical evaluation of subsurface reservoir sandstone of Bengal Basin, Bangladesh. Journal Geo Science of India 76, 621-631.

[6] Rahman MM, Wobaidullah ASM, Imam B \& Rahman, MM (2009), Evaluation of Reservoir Sands of Titas-15 Well by Wireline log interpretation. Bangladesh Geoscience Journal 15, 67-75

[7] Islam ARMT, Habib MA, Islam MT \& Mita MR (2013), Interpretation of wireline $\log$ data for reservoir characterization of the Rashidpur Gas Field, Bengal Basin, Bangladesh. IOSR Journal of Ap- plied Geology and Geophysics (IOSR-JAGG) 1 (4), 47-54, DOI10.9790/0990-0144754.

[8] Islam ARMT \& Islam MA (2014), Evaluation of Gas Reservoir of the Meghna Gas Field, Bangladesh Using Wireline Log Interpretation. Universal Journal of Geosciences 2(2), 62-69. DOI: 10.13189/ujg.2014.020204.

[9] Alam MM, Curray JR, Chowdhury MLR \& Gani MR (2003), An overview of the sedimentary geology of the Bengal Basin in relation to the regional tectonic framework and basin fill history. Sedimentary Geology 155, 179-208.

[10]Bangladesh Petroleum Exploration Production Company (BAPEX) (1989), Interpretation Report on the greater Bakhrabad Structure. Data Centre, Petrobangla, Dhaka.

[11]Bangladesh Oil, Gas, Mineral and Corporation (BOGMC) (1990), Well Completion Report, Bakhrabad \#10, Geological Evaluation Division. Petrobangla, Dhaka.

[12] Schlumberger (1974), Log interpretation, Volume-II-Principles; Houston, Schlumberger Well Services Inc.

[13]Dresser Atlas (1979), Log Interpretation Charts; Houston, Dresser Industries. Inc. pp.107.

[14]Schlumberger (1979), Log Interpretation Charts; English Metric, Schlumberger publication.

[15] Simandoux P (1963), "Mesures dielectriques en milieu poreux, application a mesure des saturations en eau, Etude du Comportment des massifs Argileux"; Revue de I'Institut Francais du Petrol, Supplementary Issue.

[16]Fertl WH (1975), Shaly-sand analysis in development wells. Soc. Professional Well Log Analysis, $16^{\text {th }}$ Ann Logging Symp. Trans., Paper $A$.

[17]Schlumberger (1975), A Guide to well site interpretation of the Gulf Coast: Houston, Schlumberger Well Services, Inc.

[18] Bateman RM and Konen CE (1977), The log analyst and the programmable pocket calculator; The log Analyst 18 (5), 3-11.

[19]Coates G and Dumanoir JL (1973), A new approach to improve logderived permeability; Society of Professional Well Log Analysis. $14^{\text {th }}$ Ann. Logging Symp. Trans. Paper R.

[20]Wyllie MRJ and Rose WD (1950), some theoretical considerations related to the quantitative evaluations of the physical characteristics of reservoir rock from electric log data. Journal Petroleum Technology $189,105-110$

[21] Archie GE (1942), The Electrical Resistivity Log as an aid in determining some reservoir characteristics. Petroleum Technology 5, 5462

[22] Morris RL and Biggs WP (1967), Using log-derived values of water saturation and porosity. Soc. Professional Well Log Analysts. $8^{\text {th }}$ The Ann. Logging symp., pp. 13

[23] Asquith GB \& Gibson CR (1982), Basic well log analysis for geologists; Text book, AAPG, Tulsa, Okalhoma, USA, pp. 216

[24]Schlumberger (1972), Log Interpretation, Volume-I-Principles. Houston, Schlumberger Well Services Inc.

[25]Fertl, WH and Vercellino WC (1978), Predict water cut from well logs, in practical log analysis-4. Oil and Gas Journal.

[26] Eze MO, Mode AW \& Ugbor CC (2013), Formation evaluation of X7 field in the Niger Delta: evidence from Petrophysical data. Niger Delta, Nigeria. IOSR Jour. of Appl. Geo. and Geoph. 1 (4), 15 -21.

[27] Amigun JO, Olisa B \& Fadeyi OO (2012), Petrophysical analysis of well logs for reservoir evaluation: A case study of 'Laja' Oil Field, Niger Delta. Journal of Petroleum and Gas Exploration Research 2(10), 181-187.

[28] Richardson AAM (2013), Well Correlation and Petrophysical Analysis, a Case Study of "Rickie" Field Onshore Niger Delta. The Inter. Jour. of Engi. And Scie. 2 (12), 4-99.

[29] Ajisafe YC and Ako BD (2013), 3-D seismic attributes for reservoir characterization of "Y" field Niger Delta, Nigeria. IOSR Jour. of Appl. Geo. and Geoph. 1(2), 23 -31, 2013. DOI: 10.9790/0990-0122331.

[30] Adeoti L, Onyekachi N, Olatinsu O, Fatoba J \& Bello M (2014), Static Reservoir Modeling Using Well Log and 3-D Seismic Data in a $\mathrm{KN}$ Field, Offshore Niger Delta, Nigeria. International Journal of $\mathrm{Ge}$ osciences 5, 93-106. DOI: 10.4236/ijg.2014.51011.

[31] Asquith G and Krygowski D (2004), Relationships of Well Log Interpretation in Basic Well Log Analysis Method in Exploration Series. American Association of Petroleum Geologists, No.16, 140. 